\title{
Analisis Tipikal Erupsi Gunung Lokon Periode Erupsi 2012-2013 Berdasarkan Karakterisasi Mikrostruktur Abu Vulkanik
}

\author{
Dolfi Paulus Pandara ${ }^{*}$ \\ aJurusan Fisika, FMIPA, Unsrat, Manado
}

\section{KATA KUNCI}

Gunung Lokon

Viskositas

Permeabilitas

Fragmentasi gelas

Vulkanian

\begin{abstract}
A B S TR A K
Gunung Lokon yang berada di lengan utara Sulawesi adalah salah satu gunung api paling aktif di Indonesia. Perilaku erupsinya telah dipelajari melalui analisis mikrostruktur abu vulkanik. Tujuan dari karakterisasi mikrostruktur adalah untuk mengestimasi nilai dari viskositas dan permeabilitas magma. Karakterisasi mikrostruktur menggunakan XRD, FTIR, SEM/EDS/XRF dan $\mu$ CT. Abu vulkanik Lokon adalah mineral polimorf yang banyak mengandung kristal plagioklase. Abu Lokon mempunyai kandungan air 0,3 -0,6\% berat dan massa dasarnya terdiri dari partikel vesikular dan non vesikular. Viskositas dari magma Lokon adalah sekitar $10^{7}$ Pa.s pada $1000^{\circ} \mathrm{C}$ dan fraksi volume kristal sekitar 0,45-0,5. Hasilhasil ini menunjukkan bahwa reologi magma Lokon adalah bersifat non Newtonian dan mekanisme fragmentasinya adalah brittle fragmentation. Berdasarkan pada permeabilitas dan porositas yang dikuantisasi dengan $\mu \mathrm{CT}$ dapat disimpulkan bahwa fragmentasi magmanya tidak dipicu oleh outgassing. Dinamika erupsi eksplosif dari Gunung Lokon pada 20122013 adalah erupsi vulkanian pada skala sedang.
\end{abstract}

KE Y W O R D S

Mount Lokon

Viscosity

Permeability

Glass fragmentation

Vulkanian

\begin{abstract}
A B S T R A C T
Lokon volcano where located on North arm of Sulawesi is one of the most active volcanoes in Indonesia. Behaviour of its eruptions have been learned through microstructure analysis of volcanic ash. The goal of microstructure characterization is estimate value of magma viscosity and permeability. Characterization of microstructure using XRD, FTIR, SEM/EDS/XRF and $\mu C T$. Lokon volcanic ash is a polymorph minerals which contains many plagioclase crystal. Ash has water content between 0.3 $0.6 \%$ wt and its groundmass contains vesicular and non vesicular particles. Viscosity of Lokon magma is about $10^{7} \mathrm{~Pa}$.s at $1000^{\circ} \mathrm{C}$ and fraction of crystal volum between 0.45-0.5. These results showed that magma rheology of Lokon is non Newtonian and the mechanism of its fragmentation is brittle fragmentation. Based on permeability and porosity that quantified by $\mu \mathrm{CT}$, it is concluded that the brittle fragmentation is not triggered by outgassing. Dynamics of explosive eruption of Lokon volcano at 2012-2013 is moderate vulcanian eruption.
\end{abstract}

TERSEDIA ONLINE

01 Agustus 2017

\section{Pendahuluan}

Gunung Lokon merupakan salah satu gunungapi aktif di Indonesia yang sering erupsi (Badan Geologi, 2011). Aktivitas erupsinya dapat berupa Iontaran bom vulkanik, jatuhan pumis, lapili, hembusan gas beracun dan aliran awan panas
(Badan Geologi,2011; Suparman dkk., 2013). Aktivitas tersebut berkaitan dengan dinamika aliran fluida magmatik dan proses-proses fisika yang terjadi di dalam konduitnya. Pada umumnya, dinamika erupsi suatu gunungapi dimulai dengan injeksi aliran magma segar yang kental dan bersuhu

*Corresponding author: Jurusan Fisika FMIPA UNSRAT, Jl. Kampus Unsrat, Manado, Indonesia 95115; Email address: dpandara@yahoo.com

Published by FMIPA UNSRAT (2017) 
tinggi. Injeksi aliran magma akan meningkatkan tekanan kantung magma dan menyebabkan magma naik di dalam saluran vulkanik. Proses tersebut akan diikuti desorpsi volatile dari magma cair membentuk gelembung gas di atas permukaan eksolusi (Gonnermann \& Mangga, 2007). Pertumbuhan gelembung gas akan menyebabkan magma kental bergerak naik (Gonnermann \& Mangga, 2007; Ida, Y, 2010). Aliran magma tersebut dapat diikuti proses degassingatau outgassing dan kristalisasi magma. Proses degassingatau outgassing berkaitan dengan aliran permeabel dan berperan dalam formasi sumbat magma atau kubah lava serta aliran lava (Diller, K.,2006; Kozono, T andT. Koyaguchi, 2010), sedangkan kristalisasi magma akan berperan pada proses fragmentasi (Burgisser, A.,et-al,2011; Gonnermann \& Mangga, 2007). Fragmentasi dan Outgassing merupakan dua proses waktu pendek yang menentukan perilaku erupsi. Transisi di antara erupsi eksplosif dan efusif dikontrol oleh proses waktu pendek ini. Bila faktor outgassing cukup besar, aliran gelembung magma akan efusif dan menghasilkan aliran lava(Ida, Y. 2010. Kozono T., and T. Koyaguchi,2010)

Fragmentasi berkaitan dengan kemampuan magma untuk pecah menjadi potongan-potongan diskrit, sedangkan outgassing berkaitan dengan kemampuan gas lepas dari magma (Namiki\&Manga, 2008). Proses-proses tersebut dipengaruhi oleh reologi magma dan kandungan gas di dalam magma (Takeuchi, 2011).

Parameter yang mengontrol proses fragmentasi dan outgassing adalah viskositas magma dan permeabilitas gas. Parameterparameter tersebut dapat diinvestigasi melalui karakterisasiparametermikrostruktur abu vulkanik. Parameter mikrostruktur abu vulkanik merupakan parameter kontrol pada gerak magma dan kondisikondisi sebelum erupsi (Polacci et-al., 2006; Shea T et-al,2010). Mikrostruktur abu vulkanik menyimpan informasi tentang sifat-sifat magma dan tahapan proses sejak magma naik dari kantung magma sampai keluar dari kawah. Melalui karakterisasi dan analisa mikrostruktur abu, mekanisme erupsi Gunung Lokon pada periode 2012-2013 dapat dipahami sebagai informasi yang penting dalam memprediksi perilaku erupsi di masa yang akan datang.

\section{Material dan Metode}

Karakterisasi morfologi, jenis mineral, komposisi kimia, dan kandungan air di dalam abu vulkanik hasil erupsi Gunung Lokon periode 20122013 dilakukan menggunakan SEM (Scanning Electron Microscopy). XRD (X-ray diffractometer), EDS (Energy Dispersive X-ray Spectroscopy) dan XRF (X-ray Fluorecency) serta FTIR (Fourier Transform Infra Red). Hasil-hasil karakterisasi tersebut digunakan untuk mengestimasi parameter reologi yaitu viskositas magma. Sedangkan untuk menentukan kandungan vesikel dan parameter permeabilitas, abu dikarakterisasi menggunakan mikrotomografi sinar $X$ tiga dimensi $(\mu \mathrm{CT})$ dengan resolusi tinggi $30 \mu \mathrm{m} /$ pixel. Sampel abu dimasukkan ke dalam wadah berbentuk silinder dengan panjang $27 \mathrm{~mm}$ dan diameter $5 \mathrm{~mm}$. Tegangan SkyScan1173 dioperasikan pada 100 kV dengan sumber arus $80 \mu \mathrm{A}$. Hasil perekaman melalui rotasi sampel sebesar 3600 menghasilkan grafik mikro antara 1191 sampai 1625 buah untuk 5 buah sampel. Citra tekstur abu beserta parameterparameter morfometriknya direkonstruksi dan dikalkulasi menggunakan perangkat lunak Nrecon, Ctan, dan ImageJ. Selanjutnya, permeabilitas abu dimodelkan menggunakan simulasi kisi Boltzmann, perangkat lunak Palabos dan Paraview (Latief F.D.E. et al, 2013)

\section{Hasil dan Pembahasan \\ Hasil Karakterisasi XRD}

Analisis kandungan fasa mineral pada abu vulkanik dengan menggunakan metode XRD menunjukkan bahwa abu vulkanik merupakansuatu mineral poliamorf. Spektrum XRD dari sampel abu yang dianalisis menunjukkan puncak-puncak spektral yang dominan tajam dan intesitas yang cukup tinggi yaitu pada sudut 2 theta sekitar 210230, 270-280, 300 dan 330-350 (Gambar 1).

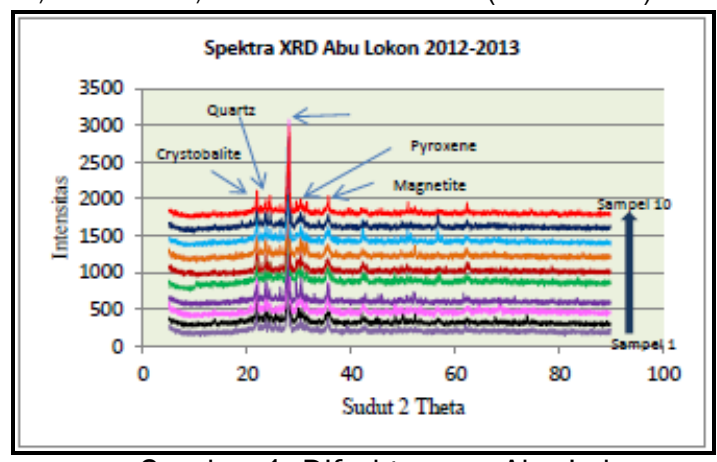

Gambar 1. Difraktogram Abu Lokon

Puncak-puncak spektral tersebut di atas berkaitan dengan massa dasar dari abu Lokon yang terdiri dari campuran mikrolit dan mineral silika (partikel gelas). Fase mikrolit berupa plagioklase $\left(\mathrm{CaAl}_{2} \mathrm{Si}_{2} \mathrm{O}_{8}\right)$, piroksen $\left(\mathrm{Mg}_{2} \mathrm{Si}_{2} \mathrm{O}_{6}\right)$ dan oksida Fe-Ti. Plagioklase dan Piroksene merupakan fasa silicious dengan komponen kimia utama adalah $\mathrm{SiO}_{2}$. Mineral Plagioklase berupa Anorthite, mineral Piroksen berupa Diopside dan mineral oksida Fe-Ti berupa Magnetite. Sedangkan mineral silika merupakan fasa polimorf-kristalin $\left(\mathrm{SiO}_{2}\right)$ yang terdiri dari Crystobalite dan Quartz. Hasil ini megindikasikan bahwa abu vulkanik yang dianalisismerupakan produk erupsi vulkanian (Giachetti et-al, 2011).

\section{Hasil FTIR}

Karakterisasi FTIR (Fourier Transform Infrared Spectrophotometri) dari abu Lokon menunjukkan vibrasi ikatan $\mathrm{Si}-\mathrm{O}, \mathrm{H}-\mathrm{O}-\mathrm{H}$ dan $\mathrm{O}-\mathrm{H}$ bersesuaian dengan pita absorbansi sekitar $1018 \mathrm{~cm}^{-1}$ 1093,64 cm-1, $1523 \mathrm{~cm}^{-1}$ - 1627,9 $\mathrm{cm}^{-1}$ dan $3448,72 \mathrm{~cm}^{-1} \quad-3452,6 \mathrm{~cm}^{-1}$ (Gambar 2). Absorbansi pita $1523 \mathrm{~cm}^{-1}$ - 1627,9 $\mathrm{cm}^{-1}$ dan pita 
$3448,72 \mathrm{~cm}^{-1}-3452,6 \mathrm{~cm}^{-1}$ dapat digunakan untuk menentukan kandungan air (dissolvedwater) menurut Hukum Lambert-Beer(Newman et al,1986; Miwa T and A. Toramaru,2013). Ketebalan efektif partikel gelas dapat diukur dari absorbansi ikatan Si-O pada pita $1018 \mathrm{~cm}^{1}$ - 1093,64 $\mathrm{cm}^{-1}$ (Miwa T and A. Toramaru,2013). Absorptivitas molar untuk pita yang berkaitan dengan kandungan air total (molekul air ditambah grup $\mathrm{OH}$ ) adalah $75 \pm 4 \mathrm{Lmol}^{-}$ ${ }^{1} \mathrm{~cm}^{-1}$, dan densitas partikel gelas riolitik diasumsikan $2.430 \mathrm{~g} / \mathrm{L}$ (Newman et al,1986 , Okumura et-al, 2003).

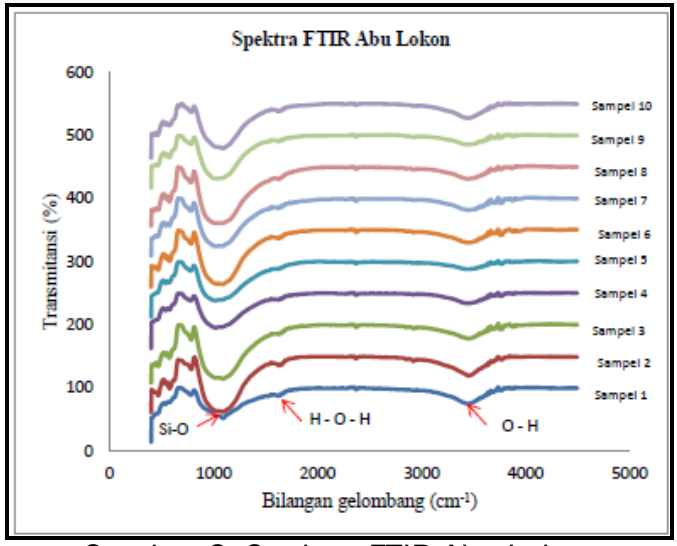

Gambar 2. Spektra FTIR Abu Lokon

Kandungan air terdapat pada partikel gelas merupakan indikator tekanan kantung magma dangkal. Kandungan air dalam abu Lokon pada 10 sampel abu yang dianalisis berkisar 0,3 - 0,6\% berat. Kandungan air pada level di atas 0,409\% berelasi dengan letusan yang disertai dentuman kuat dan tinggi kolom erupsi mencapai $2000 \mathrm{~m}$ atau lebih (Gambar 3). Hasil riset Miwa $T$ and $A$. Toramaru (2013) menunjukkan bahwa partikel abu dengan kandungan air lebih dari 0,4\% berat relatif berkaitan dengan kandungan gelembung (VND) yang lebih banyak di dalam magma.

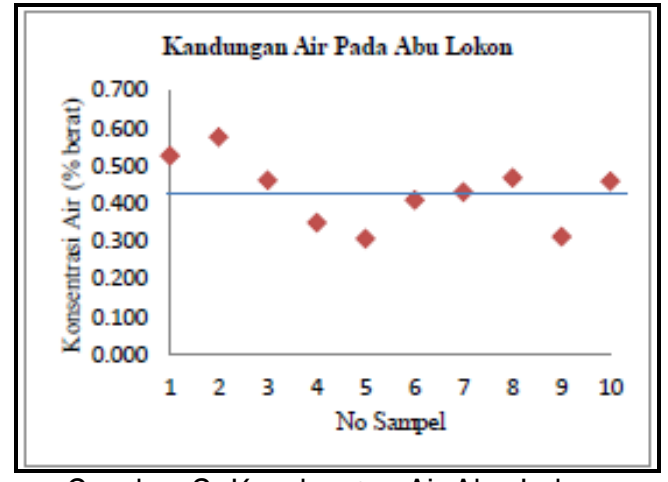

Gambar 3. Kandungan Air Abu Lokon

\section{Hasil Karakterisasi SEM-EDS}

Citra SEM abu Lokon (Gambar 4) menunjukkan bahwa massa dasar abu terdiri partikel bervesikel dan yang tidak bervesikel. Keberadaan vesikel berkaitan dengan kandungan gas termasuk $\mathrm{H}_{2} \mathrm{O}$ di dalam magma. Komposisi kimia partikel abu vulkanik Gunung Lokon dikarakterisasi dengan XRF dan EDS yang difokuskan pada partikel yang bervesikel (Tabel 1).

Tabel 1. Komposisi Kimia Abu Lokon

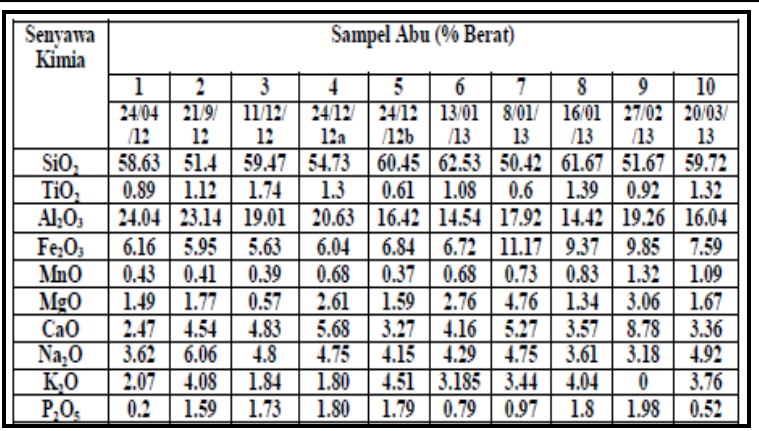

Komposisi kimia menunjukkan bahwa magma Lokon pada periode 2012-2013 mempunyai kandungan $\mathrm{SiO}_{2}$ yang cukup tinggi. Kandungan tersebut menyebabkan magma bersifat asam dan berkorelasi dengan letusan yang bersifat eksplosif yang dominan terjadi pada periode 2012-2013.

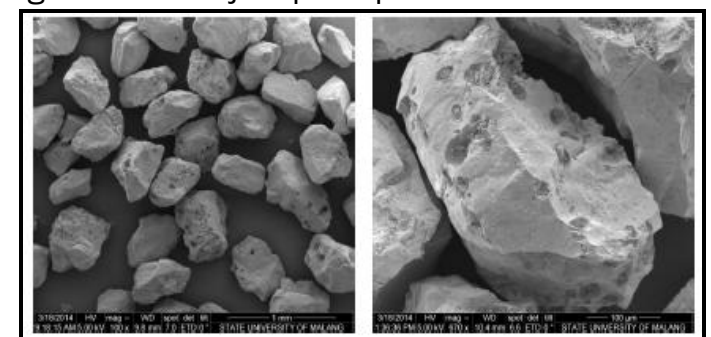

Gambar 4. Citra SEM Abu Lokon

Komposisi keseluruhan sampel abu Lokon adalah basaltik-andesitik namun massa dasar partikel gelas adalah basaltic trachy-andesite sampai trachy-andesite berkaitan dengan kandungan kalium $\left(\mathrm{K}_{2} \mathrm{O}\right)$ dan potassium $\left(\mathrm{Na}_{2} \mathrm{O}\right)$ yang tinggi (Gambar 5). Hal ini menunjukkan bahwa magma pada periode letusan 2012-2013 merupakan magma baru (fresh magma) yang kaya kristal (plagioclase) dan berasal dari daerah kantung magma yang lebih dangkal. Kandungan Anorthite (plagioclase) dalam sampel abu mendukung bahwa magma berasal dari suatu perhentian sementara di kedalaman yang lebih dangkal dan berkaitan dengan proses kristalisasi yang terjadi selama erupsi (Preece, K. et al,2013). Trachy-andesite yaitu magma dengan sedikit kandungan kuarsa tetapi didominasi alkali feldspar dan plagioklase serta piroksen seperti ditunjukkan pada spektra XRD. Magma tipe ini dapat menghasilkan letusan eksplosif Vulkanian bahkan Plinian.

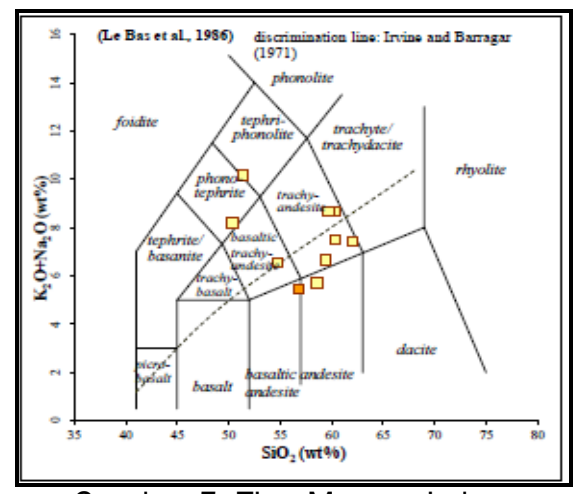

Gambar 5. Tipe Magma Lokon

Berdasarkan data komposisi dan kandungan air abu vulkanik maka viskositas magma 
dikuantitifikasi. Di dalam perhitungan, temperatur magma divariasikan dari $700^{\circ} \mathrm{C}-1200^{\circ} \mathrm{C}$ dan magma diasumsikan bersifat hidrous.

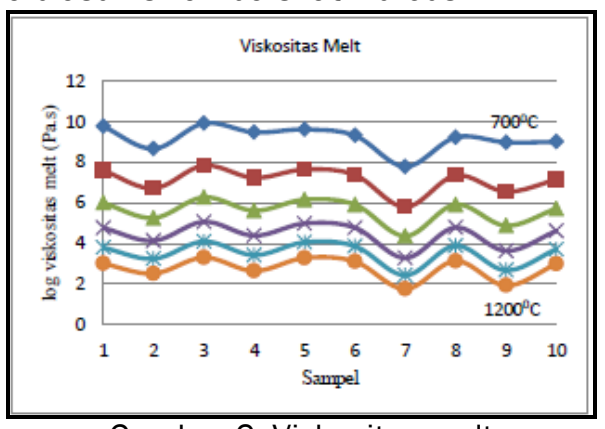

Gambar 6. Viskositas melt

Viskositas magma sangat bergantung kuat pada temperatur, kandungan $\mathrm{SiO}_{2}$, kandungan air dan fraksi kristal dalam magma (Gambar 6 dan Gambar 7). Penurunan temperatur magma menyebabkan viskositas melt meningkat.Magma dengan jumlah komposisi $\mathrm{SiO}_{2}$ di bawah $55 \%$ memiliki nilai viskositas yang lebih kecil. Komposisi $\mathrm{SiO}_{2}$ yang lebih sedikit berkaitan dengan proses diferensiasi magma karena variasi tekanan dan temperatur saat magma berdinamika dari kedalaman ke tempat yang lebih atas. Semakin tinggi kandungan $\mathrm{H}_{2} \mathrm{O}$ semakin kecil nilai viskositas. Kandungan $\mathrm{H}_{2} \mathrm{O}$ dalam cairan silika dapat memutuskan ikatan polimer cairan silika, dan polimer yang lebih pendek menghasilkan viskositas yang lebih rendah (Mookherjee, M. et-al,2008; Humaida dkk, 2011). Fraksi kristal dalam magma akan meningkatkan viskositas magma. Kandungan plagioklase yang dominan pada spektra XRD abu Lokon mengindikasikan bahwa fraksi kristal dalam magma cukup signifikan berelasi dengan viskositas magma. Peningkatan jumlah kristal dalam magma akan meningkatkan viskositas dan terbentuk jaringan kristal yang menghambat pertumbuhan gelembung gas dan mendorong terjadinya fragmentasi (Namiki and Mangga, 2008).

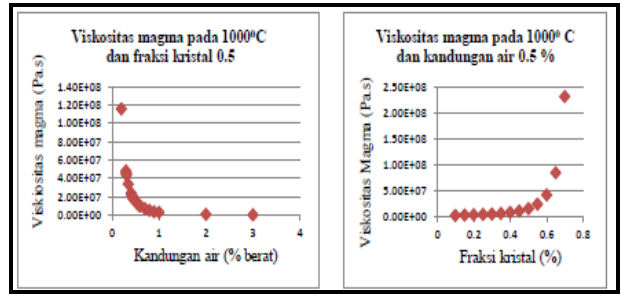

Gambar 7. Viskositas Magma

Hasil perhitungan menunjukkan bahwa pada temperatur $1000{ }^{\circ} \mathrm{C}$ dan kandungan air antara 0.3 - $0.6 \%$, viskositas magma Lokon berada pada level $10^{7}$ Pa.s dengan fraksi volume kristal 0.45 - 0.5. Berdasarkan nilai viskositas tersebut maka mekanisme fragmentasi yang terjadi pada periode erupsi 2012-2013 dominan adalah fragmentasi magmatik berupa fragmentasi gelas (brittle fragmentation) (Alidibrov M. and D.B. Dingwell, 2000).Fragmentasi gelas terjadi karena magma bertransisi dari fasa cair (ductile behaviour) ke fasa gelas (brittle behaviour). Pada level fraksi kristal di atas, reologi magma Lokon adalah bertipe Non
Newtonian dimana viskositas bergantung pada laju regangan. Pada laju regangan yang besar magma berkelakuan sebagai padatan yang mekanisme kerapuhannya didominasi sifat elastik (brittle). Sedangkan pada laju regangan yang kecil, magma berkelakuan sebagai fluida kental dan mekanisme retakannya didominasi sifat plastis (ductile). Hasil ini terkonfirmasi dengan observasi visual yang menunjukkan bahwa erupsi Lokon pada periode 2012-2013 adalah erupsi magmatik ditandai dengan bunyi dentuman yang keras dan adanya Iontaran material pijar.

\section{Hasil Karakterisasi $\mu$-CT}

Tekstur abu Lokon (Gambar 4 dan Gambar 8) menunjukkan adanya gelembung gas (vesikel) di dalam magma. Hal ini menyatakan bahwa magma Lokon bersifat vesikular di mana viskositas mengisolir gas di dalam magma. Gas yang terperangkap akan mengalami ekspansi dan dapat keluar dari magma (outgassing).

Proses outgassing menentukan tipe letusan dan eksplosivitas erupsi. Proses ini ditentukan oleh parameter permeabilitas magma. Semakin banyak gelembung gas yang terperangkap semakin potensial terjadi letusan eksplosif. Kuantifikasi terhadap tekstur abu menghasilkan nilai-nilai parameter permeabilitas, porositas, rapat jumlah vesikel, tekanan ambang fragmentasi dan rapat energi ambang seperti ditampilkan pada Tabel 2. Parameter-parameter ini digunakan untuk menganalisa tipikal letusan yang terjadi.

Permeabilitas akan mempengaruhi proses fragmentasi hanya jika koefisien permeabilitas (k) memiliki nilai di atas nilai kritis $\left(\sim 10^{-12} \mathrm{~m}^{2}\right)$ (Mueller et al, 2008). Bila nilai $\mathrm{k}>10^{-12} \mathrm{~m}^{2}$, rapat energi ambang akan meningkat tajam dan permeabilitas bersifat memperlambat proses fragmentasi. Bila nilai permeabilitas semakin besar di atas nilai kritis maka semakin banyak gas yang dapat lolos (outgassing) sehingga rapat energi minimum yang diperlukan untuk terjadinya fragmentasi makin besar pula. Koefisien permeabilitas yang dikuantisasi pada sampel dalam penelitian ini lebih kecil nilainya dibandingkan dengan nilai permeabilitas kritis. Hal ini berarti bahwa faktor outgassing bukanfaktor penggerak utama terjadinya fragmentasi magma.

Tabel 2 Permeabilitas dan Porositas

\begin{tabular}{|c|c|c|c|c|c|c|c|}
\hline \multirow{2}{*}{$\begin{array}{c}\text { Sampel } \\
\mathrm{No}_{0}\end{array}$} & \multirow{2}{*}{$\begin{array}{l}\text { Tanggal } \\
\text { Erupsi }\end{array}$} & \multicolumn{2}{|c|}{$\Phi$} & \multirow{2}{*}{$\mathbf{k}\left(\mathrm{m}^{2}\right)$} & \multirow{2}{*}{$\begin{array}{c}\rho_{\mathrm{E}, \mathrm{s}} \\
\left(\mathrm{MMJ}^{3} /\right. \\
\left.\mathrm{m}^{3}\right)\end{array}$} & \multirow{2}{*}{$\begin{array}{c}\mathrm{P}_{\mathrm{i}} \\
\text { (MPa } \\
\text { ) }\end{array}$} & \multirow{2}{*}{$\begin{array}{l}\text { VND } \\
\left(\mathrm{m}^{-3}\right)\end{array}$} \\
\hline & & $\%$ & & & & & \\
\hline 2 & $21 / 9 / 2012$ & 12.49 & \begin{tabular}{|l|l|}
0.1249 \\
\end{tabular} & $2.21 \mathrm{E}-13$ & 0.156 & 1.25 & $5.43 \mathrm{E}+14$ \\
\hline 3 & $11 / 12 / 2012$ & \begin{tabular}{|l|}
9.92 \\
\end{tabular} & \begin{tabular}{|l|}
0.0992 \\
\end{tabular} & \begin{tabular}{|l|l}
$4.46 \mathrm{E}-14$ \\
\end{tabular} & 0.110 & 1.11 & $4.78 \mathrm{E}+14$ \\
\hline 7 & $8 / 1 / 2013$ & 5.65 & 0.0565 & $4.41 \mathrm{E}-15$ & 0.059 & 1.04 & $3.44 \mathrm{E}+14$ \\
\hline 6 & $13 / 1 / 2013$ & 3.78 & 0.038 & $5.97 \mathrm{E}-16$ & 0.038 & 1.01 & $3.15 \mathrm{E}+14$ \\
\hline 8 & $16 / 1 / 2013$ & 12.53 & 0.125 & \begin{tabular}{|l|}
$3.81 \mathrm{E}-14$ \\
\end{tabular} & 0.138 & 1.10 & $5.77 \mathrm{E}+44$ \\
\hline
\end{tabular}

Proses fragmentasi bergantung pula pada porositas magma yang berkaitan dengan keluwesan aliran gas. Porositas menentukan jumlah total gas bertekanan lebih yang dapat tersimpan dalam magma. Semakin besar porositas akan semakin banyak gas yang dapat melakukan 
penetrasi ke dalam matriks magma. Tekanan lebih gas di dalam matriks akan mengatasi kekuatan regangan matriks sehingga fragmentasi dapat terjadi. Semakin besar porositas maka ambang fragmentasi yang diperlukan semakin kecil. Hasil kuantisasi menunjukkan bahwa porositas sampel abu Lokon memiliki nilai yang kecil Hal ini berarti untuk terjadinya fragmentasi diperlukan tekanan ambang fragmentasi yang besar. Porositas yang rendah tidak mendukung untuk picuan fragmentasi digerakkan oleh proses outgassing.

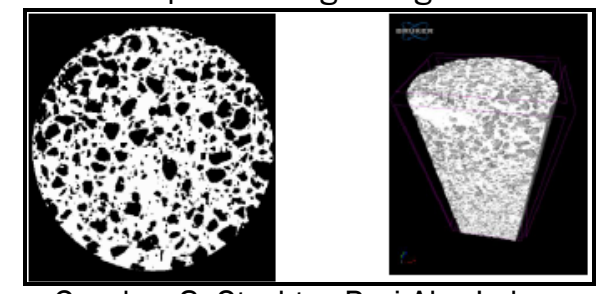

Gambar 8. Struktur Pori Abu Lokon

Mekanisme yang mungkin untuk menyebabkan terjadinya fragmentasi magma adalah mekanisme dekompresi tekanan secara tiba-tiba yaitu mekanisme letusan Vulkanian.Hasil observasi visual terhadap profil letusan dan material piroklastik yang dihasilkan mendukung kesimpulan bahwa tipe erupsi magmatik Lokon pada periode 2012-2013 adalah tipe Vulkanian. Letusan Lokon pada periode ini didominasi oleh material abu dan ditemukan pula adanya bom kerak roti sebagai penanda letusan Vulkanian (Wright, H.M.N et al, 2007).

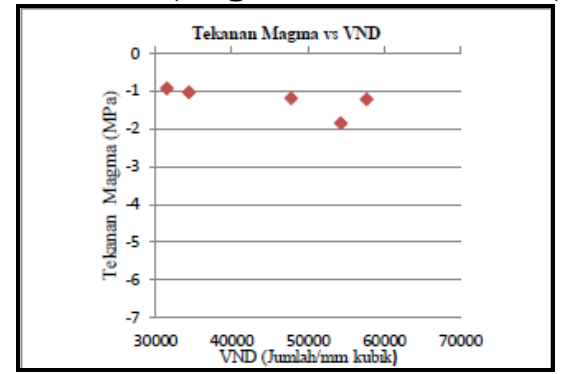

Gambar 9. Tekanan Magma

Kandungan vesikel yang lebih banyak dalam magma berkorelasi dengan kadar air yang lebih tinggi di dalam massa dasar abu. Magma yang mempunyai kadar air yang lebih tinggi berasal dari daerah yang lebih dalam di bawah kawah. Gambar 9 menunjukkan bahwa magma dengan kandungan vesikel yang lebih besar terkait dengan tekanan magma yang lebih tinggi (Toramaru, A., 2006). Tekanan yang lebih tinggi menunjukkan asal magma dari tempat yang lebih dalam. Tekanan yang tinggi akan mendorong magma lebih kuat sehingga kolom erupsi akan lebih tinggi. Magma yang mempunyai tekanan di atas $1 \mathrm{MPa}$ berkaitan dengan letusanvulkanian yang tinggi kolom erupsinya lebih dari 2000 m. Tekanan yang tinggi disebabkan adanya akumulasi gas akibat proses degassing. Magma yang bersifat vesikular akan mengalami proses degassing dan akan menjadi magma miskin gas pada saluran vulkanik dangkal dan kristalisasi dan sebagian membentuk sumbat magma( Diller, $\mathrm{K}$. et al , 2006;Burgisser, A.,et-al,2010). Terjadi sirkulasi antara magma kaya vesikel dengan magma yang miskin gas sebagai persiapan untuk terjadinya letusan Vulkanian (Miwa and Toramaru, 2013).Bila terjadi dekompresi akibat retakan pada sumbat magma makaterjadilah letusan vulkanian (Burgisser, A.,et-al,2010; Diller, K.,2006).

\section{Kesimpulan}

Mikrostruktur abu letusan memberikan informasi bahwa magma lokon bersifat andesit dan vesikular. Variasi nilai viskositas terhadap kandungan air dan fraksi kristal menunjukkan bahwa reologi magma Lokon adalah Non Newtonian. Nilai permeabilitas dan porositas menunjukkan bahwa mekanisme vulkanian di Gunung Lokon tidak disebabkan oleh proses outgassing tetapi berkaitan dengan suatu dekompresi tekanan yang tiba-tiba di bawah sumbat magma.Berdasarkan kajian yang telah dilakukan di dalam penelitian ini dapat disimpulkan bahwa tipikal erupsi eksplosif Gunung Lokon pada periode erupsi 2012-2013 adalah bertipe vulkanian moderat

\section{Daftar Pustaka}

Alidibirov, M., and D.B. Dingwell. 2000. Three fragmentation mechanisms for highly viscous magma underrapid decompression. Journal of Volcanology and Geothermal Research 100 : 413-421

Badan Geologi. 2011. Data Dasar Gunungapi Indonesia. Edisi Kedua. Kementerian Energi dan Sumber Daya Mineral Republik Indonesia

Burgisser, A.,L. Arbareth, T.H. Druitt, and T. Giachetti. 2010. Pre-explosive conduit condition of the 1997 Vulcanian explosions at Soufriere Hills Volcano, Monstserat: II. Overpressure and depth distributions. Journal of Volcanology and Geothermal Research (199) : 1-26. Doi:10.1016/j.jvlgeores.2010.11.014

Diller, K., Clarke, A.B., Voight, B. dan Neri,2006, Mechanisms of conduit plug formation: Implication for vulcanian explosions: Geophysical Research Letters, Vol. 33, L20302, doi:10.1029/2006GL027391, 2006.

Giachetti T, A. Burgisser, L. Arbaret, T.H. Druit, and K. Kelfoun. 2011. Quantitative textural analysis of Vulcanian pyroclasts (Monserrat) using multiscale X-ray computed microtomography: comparison with results from 2D image analysis. Bulletin of Volcanology (Article in press) Doi: 10.1007/s00445-011-0472-1

Gonnermann,H.M.,and M. Mangga. 2007. The Fluid Mechanics Inside Volcano. The Annual Review of Fluid Mechanics 39 : 321-356

Humaida, K., K.S. Brotopuspito, H.D. Pranowo, dan Narsito. 2011. Pemodelan Perubahan Densitas dan Viskositas Magma Serta Pengaruhnya terhadap Sifat Erupsi Gunung Kelud. Jurnal Geologi Indonesia 6 : 227-237

Ida, Y. 2010. Computer simulation of time dependent magma ascent processes involving bubbly and gasy flows. Journal of Volcanology and Geothermal Research 196 : 45-56 
Kozono T., and T. Koyaguchi.2010. A simple formula for calculating porosity of magma in volcanic conduits during dome-forming eruptions. Earth Planet Space 62 : 483-488.

Latief F.D.E, U. Fauzi and S. Feranie, 2013. Digital isolation technique for reconstruction and visualization of crack in micro CT- images of geothermal reservoir rock. Microscopy and Analysis-Asia Pacific Isue 103, March/April 2013

Miwa T., A. Toramaru, and M. Iguchi. 2013. Conduit process in vulcanian eruptions at Sakurajima volcano, Japan: Inference from comparison of volcanic ash with pressure wave and seismic data. Bulletin Volcanology 75 : 685 (1-13)

Mookherjee M., Stixrude L., and B. Karki.2008. Hydrous silicate melt at high pressure Nature Vol 452,2008

Mueller,S., B. Scheu, O. Spieler, and D.B. Dingwell. 2008. Permeability control on magma fragmentation. Geology 36 (5) : 399-402

Namiki A., and M. Manga. 2008. Transition between fragmentation and permeable outgassing of low viscosity magmas. Journal of Volcanology and Geothermal Research 169 : 48-60

Newman S., Stolper, E.M., and S. Epstein.1986. Measurement of water in rhyolitic glasses: Calibration of an infrared spectroscopic technique. American Mineralogist, Volume 71, pages 1527-1541

Okumura, S., Nakamura M., and S. Nakashima. 2003. Determination of molar absorptivity of IR fundamental $\mathrm{OH}$-stretching vibration in rhyolitic glasses.American Mineralogist, Volume 88, pages 1657-1662, 2003.

Preece K., Barclay J., Ralf Gertisser R., and R. A. Herd. 2013. Textural and micro-petrological variations in the eruptive products of the 2006 dome-forming eruption of Merapi volcano, Indonesia: Implications for sub-surface processes. Journal of Volcanology and Geothermal Research. VOLGEO-05083; No of Pages 23

Polacci M., D.R. Baker, L. Mancini, G. Tromba, and F. Zanini. 2006. Three-dimensionalinvestigation of volcanic texture by X-ray microtomography and implications for conduit processes. Geophysical Research Letters 33 (L13312):1-5

Suparman dkk, 2013. Erupsi Gunung Lokon berdasarkan kegempaan, deformasi, dan geokimia pada Januari 2013. Jurnal Lingkungan dan Bencana Geologi Vol 4 No 3 Desember 2013.

Shea T, B.F. Houghton, L. Gurioli, K.V. Cashman, J.E. Hammer, and B.J. Hobden.2010. Textural studies of vesicles in volcanic rocks: an integrated methodology. Journal of Volcanology and Geothermal Research $190: 271-289$

Takeuchi, S. 2011. Preruptive magma viscosity: An important measure of magma eruptibiliy. Journal of Geophysical Research 116(B10201) :1-19
Toramaru, A. 2006. BND (bubble number density) decompression rate meter for explosive volcanic eruptions. J Volcanol Geotherm Res.154(34):303-316

Wright, H.M.N., Cashman K.V., Rosi M.,and R.Cioni. 2007. Breadcrust bombs as indicators of Vulcanian eruption dynamicsat Guagua Pichincha volcano, Ecuador. Bull Volcanol (2007) 69: 281-300DOI 10.1007/s00445006-0073-6 